\title{
Synthesized Silica Mesoporous from Silica Geothermal Assisted with CTAB and Modified by APTMS
}

\author{
Silviana Silviana $^{1 *}$, Adi Darmawan ${ }^{2}$, Atikah Ayu Janitra ${ }^{3}$, Amar Ma'ruf $^{3}$, Isabel Triesty ${ }^{3}$ \\ ${ }^{1}$ Department of Chemical Engineering, Faculty of Engineering, Diponegoro University, Tembalang, 50275 \\ Semarang, Indonesia, *silviana@ che.undip.ac.id \\ ${ }^{2}$ Department of Chemistry, Faculty of Science and Mathematics, Diponegoro University, Tembalang, 50275 \\ Semarang, Indonesia \\ ${ }^{3}$ Master Program of Chemical Engineering, Faculty of Engineering Diponegoro University, Tembalang, 50275 \\ Semarang, Indonesia
}

\begin{abstract}
Mesoporous silica is one of the modifications from silica particle; it can used as host of drug delivery. This study focused on the synthesis of mesoporous silica. The precursor of silica is sodium silicate, obtained from silica geothermal. Assisted with cetyltrimethylammonium bromide (CTAB) as a surfactant, to produce silica particle with mesoporous structure. Then modified with 3-Aminopropyltrimethoxysilane (APTMS) to modified the mesoporous silica with amine functional group, so it can be a matrix of slow-release urea fertilizer. The precursors used was sodium silicate from silica geothermal; the surfactant was $\mathrm{CTAB}$ at 0.03 molar ratio. Stöber method used in this research with the addition of ethanol, $\mathrm{NH}_{4} \mathrm{OH}, \mathrm{CTAB}$, and water with a mol ratio of 10: 22.8: 0.03: 5.2 to 1 mol sodium silicate, respectively. The mesoporous silica characterized by using BET and FTIR. It is then modified with (APTMS) to increase the absorbed urea as slow-release urea fertilizer. The mesoporous silica revealed a diameter of $15.310 \AA$ and 19.025 $\AA$ at adsorption and desorption, respectively and having the adsorption-desorption curve type of IV which classified as the mesoporous particle. The results showed that the addition of CTAB strongly influenced porosity of silica particles. Several functional groups indicate ammonia from APTMS have modified the mesoporous silica, such as $2930 \mathrm{~cm}^{-1}$ ascribed to the stretching modes of $\mathrm{CH}_{2}$ groups and vibrational modes at $155 \mathrm{~cm}^{-1}$ represent $\mathrm{NH}_{2}$. It approved that mesoporous silica modified with APTMS adjusted with ammonia functional group, so it proved as a matrix of slow-release urea fertilizer.
\end{abstract}

Key words : Silica geothermal, Mesoporous silica, 3Aminopropyltrimethoxysilane, Cetyltrimethylammonium bromide, Slow release

\section{INTRODUCTION}

Indonesia is known as an agricultural country, with an area of agricultural land of 7.1 million hectares, it makes Indonesia one of the countries that have potential as an agrarian country. To increase the Indonesian's growth and development in agricultural, it is necessary to improve the quality of agricultural products. Therefore, fertilizer is a significant issue in Indonesia to strengthen its agricultural products. Urea fertilizer is one type of fertilizer that is widely used because it contains nitrogen elements needed by plants. Plant only utilize the nitrogen element $30-40 \%$ when fertilizer applied to the soil [1], while $60 \%$ will lose leached in nitrates form, evaporated to the air in the form of ammonia gas and transformed into another structure that can't be used by plants [2]. Plants can adsorb nitrogen in different forms generally, in the form of $\mathrm{NH}_{4}{ }^{+}$(ammonia) and $\mathrm{NO}_{3}{ }^{-}$(nitrates) produced from the urea hydrolysis process, these changes are influenced by soil types and soil bacteria. Nitrifying bacteria able to arrange nitrate compounds from ammonia compounds which generally take place aerobically in the soil (Bernhard, 2010), then nitrogen in plants will be changed to - N, - NH and $-\mathrm{NH}_{2}[3,4]$. By applying urea fertilizer to spread it on the soil surface will increase the potential for $\mathrm{NH}_{4}{ }^{+}$turn into $\mathrm{NH}_{3}$ gas which can disappear due to evaporation. Nitrites and nitrates present in the soil can pollute the surrounding water, with the presence of nitrites and nitrates in groundwater with high concentration can cause health problems for humans [5]. To overcome these problems urea fertilizer developed by various technologies aim to decrease the urea release of urea fertilizer, one of them is by slow release fertilizer.

Slow-release fertilizer can increase the efficiency of nitrogen, so plants can absorbed nitrogen maximal and reduce pollution caused by harmful substances from urea hydrolysis. This paper will develop slow-release fertilizer using safety material and able to provide optimal results. Slow-release 
fertilizer be done through several methods, including encapsulation, and the encapsulation will synthesize urea fertilizer particles that are enveloped by added precursors, it will reduce the rate of nitrogen leaching in the soil. Slow-release encapsulated fertilizer has partially hydrophilic and hydrophobic properties. Hydrophilic nature cause the flow of water into the encapsulation layer, and nutrient transfer occurs, hydrophobic nature will reduce the rate of nutrient transfer so that the release will take place slowly [6]. Polymers and non-polymers utilized as encapsulation, such as starch, neem, renin, sulfur and other synthetic polymers [7].

The research of Zhu \& Zhuo [8] said that starch could be modified as grafted copolymerized with various monomer; each monomer that grafted on the starch will give specific properties on it. Chen et al [9] reported about the behaviour of starch-g-poly that grafted with L-lactide can modify the hydrophobic behaviour so would make the matrix swell less. Then Chen et al [10] said that The new modification of starch-g-PLLA as urea fertilizer membrane-encapsulation, the hydrophobicity of PLLA will diminish the startch's swellability and reduce urea's release rate. As a minor cell and the urea encapsulation in the changed starch film discharged through a diffusion mechanism. The use of sulfur for encapsulation of urea fertilizer can reduce the rate of dissolving of particles, and Sulphur film has a physical barrier that can protect urea particles from rainwater and groundwater. However, it is very susceptible to forming cracks or gaps caused by microbes, which can cause urea to dissolve quickly, coupled with the high cost of production processes and unstable release patterns [11]. Elastomer, amine or amine mixture with microcrystalline, paraffin can optimize the encapsulation result. But those compounds are non-biodegradable, expensive and not environmentally friendly [12].

The newly developed method is using a material that is safe and able to provide optimal results as host material for the urea fertilizer; one of them is silica. There are several sources to get silica, one of them is from silica alkoxide compounds which are generally expensive and dangerous to the environment, such as tetraethylorthosilicate (TEOS) and tetraethylorthosilicate (TMOS) [13]. Silica can found from minerals such as rocks and sand; silica is also can found in organic materials such as rice husks, bamboo leaves and other agricultural waste [14]. Affandi et al [15] used natrium silica as Si precursor to synthesis silica xerogel, the raw material is bagasse ash. The bagasse ash purified with several method, one of them is by leached it acid. It proofed that $\mathrm{Si}$ in the form of natrium silica from leached raw material can produce silica xerogel with surface area in range of $69-152 \mathrm{~m}^{2} \mathrm{~g}^{-1}$. According to Purnomo et al [16] geothermal waste or silica scaling could be one of the sources of silica with silica content approximately $88.29 \%$ and increasing to $97 \%$ after going through leaching. The silica content in geothermal waste is quite high, namely $85 \%$ amorphous silica [17]. The high of silica content will be used in this study as a source of silica, in addition to reducing geothermal waste, it can also be used as more useful research. To improve the performance of silica, it is necessary to do modifications, and modifications by modifying the structure of silica and silica's surfaces.

There are several way to improve performance of silica, one of them is by synthesis mesoporous silica. Mesoporous silica has a porous and nano-sized pore, pore space can adsorb urea well, mesoporous silica is a material that will accommodate urea, commonly called as host material [18]. Mesopore is a porous material with the appropriate meso size as a host material for large molecules and its porous structure is able to overcome the diffusion problems that are often found in micropore material [19]. Knipping et al [20] has been done research about synthesis silicon nanoparticle with microwave, this method require certain reactor so the microwave induced electrical discharge in order to dissociated the saline in low pressure flow. Even the Si particle get lower particle when the power was increase, microwave take a lot of energy in the range $300 \mathrm{Watt}-550 \mathrm{~W}$, in addition it coupled with plasma flow which is take a lot energy too.

In Fang \& $\mathrm{Hu}$ [21] reported that mesoporous silica synthesized with CMK 3 as a template, the reaction done by heating it at $38^{\circ} \mathrm{C}$ for 4 hours, then need 24 hour to successfully aged in $100^{\circ} \mathrm{C}$ condition. Thus, because the addition of copolymer it need to be canonizations by heating it on 9000 C. In Tony et al [22] using surfactants in the form of $\mathrm{N}$-lauroylsarcosine sodium, reportedly can produce products with a pore size of $3.65-3.8 \mathrm{~nm}$. In the process of synthesis of mixed mesoporous silica in the form of $\mathrm{N}$-lauroylsarcosine sodium surfactant, H2O, CSDA and TEOS homogenisation using ultrasonic homogenizer, then continued with cooling for 18 hours at $80 \mathrm{oC}$. Both previous research Fang \& Hu [21] and Tony et al [22] the synthesized is considered ineffective.

Wanyika et al [23] reported that silica precursors in the form of TEOS were modified with CTAB as a template, to form mesoporous silica. Silica with mesoporous structure has a specific area and pore with a diameter between $2-50 \mathrm{~nm}$. The use of CTAB as a mesoporous silica synthesis template known from the results of the BET test which shows an increase in surface area, pore size and pore volume [24]. Vazquez et al [24] described that using TEOS as a precursor of silica, was obtained a specific area of $1480 \mathrm{~m}^{2} / \mathrm{g}$ and pore sizes ranged from 2,5-2,8 $\mathrm{nm}$. Mesoporous silica is biocompatible [25](Popat et al., 2011), so it has the potential and save to be used as a matrix for slow release fertilizer. Surface modification can improve silica's performance by adding organotrialkoxysilan, such as APTMS (3Aminopropyltrimethoxysilane). Rahmat et al [26] use zeolite 
because it has a high silica alumina content and porous structure, zeolite activated by HF and then modified using APTMS. The use of APTMS can modify the zeolite surface by forming a $-\mathrm{NH}_{2}$ group, it can increase adsorption of urea, and decrease the release time of urea.

In this research a slow-release urea fertilizer will be developed using silica in the form of sodium silica obtained from the extraction of geothermal waste through leaching process, then synthesize mesoporous silica through addition with CTAB (Cetyltrimethylammoniumbromide), followed by modification with APTMS (Aminopropyltrimethoxysilane). The stages of the research are the preparation of geothermal silica waste, synthesize sodium silicate precursors, synthesis mesoporous silica and modification of mesoporous silica with APTMS. Followed by characterization tests covering the morphological structure using SEM-EDX, particle size using BET and functional groups using FTIR.

\section{MATERIAL AND METHOD}

\subsection{Material}

Silica geothermal obtained from Geothermal Power Plant Indonesia, CTAB (Cetyltrimethylammonium bromide) p.a produced by Sigma Aldrich, APTMS (3-Aminopropyltrimethoxysilane) produced by Sigma Aldrich, $\mathrm{NH}_{4} \mathrm{OH}$ p.a produced by Merck, Ethanol technic, $\mathrm{H}_{2} \mathrm{SO}_{4}$ (Sulfuric acid) technic, $\mathrm{NaOH}$ (Sodium hydroxide) technic, and Aquadest.

\subsection{Method}

\section{A. Silica Geothermal Leaching}

Silica geothermal as silica source was taken from Geothermal Power Plant Indonesia. To get pure silica oxide compounds, the leaching process is carried out. The silica geothermal dried to decrease its water content, then mashed into powder. The silica preparation procedure based on the method that has been carried out by Boukoussa et al [27]. The leaching process done by stirring 125 gram dried silica geothermal with $20 \%$ $\mathrm{H}_{2} \mathrm{SO}_{4}$ at $100^{\circ} \mathrm{C}$ for 105 minuets. Then, washed with aquadest until the $\mathrm{pH}$ is neutral approximately to 7 , dried $105^{\circ} \mathrm{C} 1$ hour. Mashed to obtained $\mathrm{SiO}_{2}$ (silica oxide).

\section{B. Sodium Silicate Preparation}

Sodium silicate is used to be silica precursor, the procedure preparation of sodium silicate based on Trivana et al [28]. Silica oxides 125 gram added with $4 \mathrm{~N} \mathrm{NaOH}$ solution heated at $90^{\circ} \mathrm{C}$ for 1 hour, then the sodium silica solution chill at room temperature to deposited the residual impurities. Sodium silica filtered to separate the impurities, so that sodium silicate formed. This optimal sodium silicate used as a precursor for the mesoporous silica synthesis stage.

\section{Mesoporous Silica Synthesis}

The procedure for mesoporous silica synthesis based on the method that has been carried out by Vazquez et al., [24]. Preparation of a surfactant solution by mixing 10 moles of ethanol, 22.8 moles of water, 5.2 moles of $\mathrm{NH}_{4} \mathrm{OH}$, and 0.03 of CTAB (Cetyltrimethylammonium bromide). The addition of CTAB done while stirring it on solution of ethanol, water and ammonia for 15 minutes. The sodium silicate that added dropwise to the surfactant solution by stirring continuously for 2 hours at room temperature. In the solution there will be white sediment particles. The precipitate is filtered and washed using aquadest. Then the precipitate obtained was calcined at $550^{\circ} \mathrm{C}$ to remove organic impurities. Furthermore, it characterized by BET and FTIR.

\section{Silica Mesoporous Modification}

The procedure for modifying the surface synthesis of mesoporous silica with APTMS (3-Aminopropyltrimethoxysilane) based on the method done by Zhao (2012). Mesoporous silica stirred with APTMS 10\% for 8 hours at room temperature, then dried. The modification results then characterized by FTIR.

\section{RESULT AND DISCUSSION}

Silica geothermal from geothermal power plant contains more than $85 \%$ amorphous silica [17], but still contains several heavy impurities. The metal mainly comes from metals that toxic to the human body, such as arsenic (As), lead $(\mathrm{Pb})$ and nickel $(\mathrm{Ni})$ as well as other metals [29]. To get silica with higher purity, leaching needs to be done, leaching is done by adding $20 \%$ sulfuric acid $\left(\mathrm{H}_{2} \mathrm{SO}_{4}\right)$ at $90^{\circ} \mathrm{C}$ for 105 minutes. $\mathrm{SiO}_{2}$ content could be increased because $\mathrm{SO}_{4}{ }^{2-}$ ions are highly reactive to metals, especially alkali metals and from transition groups such as $\mathrm{Fe}, \mathrm{Ni}, \mathrm{Cu}, \mathrm{Pb}$ and others. These ions will bind the impurities in the sample to form sulfate salts from metals. Whereas hydronium ions $\left(\mathrm{H}_{3} \mathrm{O}^{+}\right)$are acidic in proportion to the strength of dissolved acids $\left(\mathrm{H}_{2} \mathrm{SO}_{4}\right)$ and are also durable and concentrated. The characteristics of these two ions are interrelated so they can reduce the metal content in silica [30]. The leached silica was reacted with $4 \mathrm{~N}$ $\mathrm{NaOH}$ solution at $90^{\circ} \mathrm{C}$ for 60 minutes to obtain silica precursors in the form of sodium silicate.

Pore size classification according to IUPAC [31] based on pore diameter are micropores $(\mathrm{d}<20 \AA)$, mesoporous $(20<\mathrm{d}$ $<500 \AA$ ) and macropores (d> $500 \AA$ ). This classification is made based on the absorption of nitrogen gas at normal boiling points by porous solids with a wide range of pore sizes. Pore size distribution is an important aspect of adsorption and needed in the evaluation of porous media and membranes. The pore size distribution influences the adsorption capacity, adsorption kinetics and adsorption selectivity which is the basis in adsorbent synthesis [32]. Silica was modified with $\mathrm{CTAB}$ as a template, to form mesoporous silica. Because mesoporous silica has a porous and nano-sized pore, urea can be well adsorbed in the pore space, the ability to become a material that can accommodate 
urea, commonly called host material. The precursor of silica hydrolyzed in ethanol and ammonia as base catalyst called Stober method [33]. In this research the precursor of silica is sodium silicate, silicate hydrolyzed into silanol monomers then will be condensed to be silanol monomers into siloxane. Ammonia as base catalyst gives an important role to the kinetic balance of silica's particle growth. The average pore radius values, specific surface area and total pore volume of samples of silica mesopores compared with leached silica geothermal as seen in Table 1.

Table 1: Surface area, pore volume, and pore radius for

\begin{tabular}{|c|c|c|c|c|}
\hline Sample & Type & $\begin{array}{c}\text { Surface } \\
\text { Area } \\
\left(\mathrm{m}^{2} / \mathrm{gram}\right)\end{array}$ & $\begin{array}{c}\text { Pore } \\
\text { Volume } \\
(\text { ml/gram) }\end{array}$ & $\begin{array}{c}\text { Pore } \\
\text { Radi } \\
\text { us } \\
(\AA)\end{array}$ \\
\hline \multirow{2}{*}{$\begin{array}{c}\text { Leache } \\
\text { d Silica } \\
\text { Geother } \\
\text { mal }\end{array}$} & Desorption & 77.179 & 0.150 & $\begin{array}{c}17.03 \\
5\end{array}$ \\
\hline & Adsorption & 73.063 & 0.147 & $\begin{array}{c}17,07 \\
1 \\
\end{array}$ \\
\hline \multirow{2}{*}{$\begin{array}{c}\text { Mesopo } \\
\text { rous } \\
\text { Silica }\end{array}$} & Desorption & 287.609 & 0.368 & $\begin{array}{c}19.02 \\
5\end{array}$ \\
\hline & Adsorption & 277.012 & 0.390 & $\begin{array}{c}15.31 \\
0\end{array}$ \\
\hline
\end{tabular}

The surface area was increase from $70 \mathrm{~m}^{2} /$ gram to $280 \mathrm{~m}^{2} /$ gram on leached silica geothermal and mesoporous silica, respectively. Then reacting silica precursor with solution of mixture ethanol, water and ammonia obtained mesoporous silica with high pore volume and surface area. It caused by CTAB surfactant micelles formed as template in an ensemble of, then calcination done to remove it, so obtained mesoporous silica with high pore volume and surface area [23], indicate from the increase surface area from leached silica geothermal and mesoporous silica. Mesoporous silica is a material that has a very large surface area. Mesoporous silica has a very large surface area, a pore size that can be modified as well as a surface chemical character that can be easily modified. Thus high surface territories ought to give an enormous number of site on surface or interface for example adsorption with other atoms, ions, or molecules [34]. It's large pore volumes can provide large space to molecule can loaded into it [34], for this research is to load urea as slow release fertilizer. There are six types of isotherms classified by the International Union of Pure and Applied Chemistry (IUPAC), which are microporous, nonporous, macro porous, or mesoporous [35]. This classification relies on adsorption and desorption curves, and a hysteresis indicates mesoporous materials. In chemistry, a hysteresis defined as the deviation of the contact angle from it's theoretical (and mean) value due to physical phenomena. To further accurately indicating silica samples as mesoporous, a visual analysis may be conduct. From Figure 1 show the hysteresis curve of CTAB $0.03 \mathrm{~mol}$ because it represents isotherm curve type IV that implied a mesoporous material.

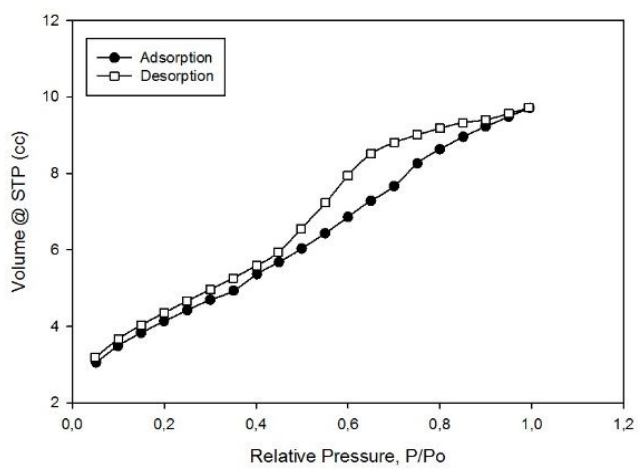

Figure 1: Hysteresis Result of Mesoporous Silica.

After the mesoporous silica obtained, to improve the ability of mesoporous silica as urea fertilizer matrix, it added with amino silane agent. Amine silane agent in this research is APTMS (3-Aminopropyltrimethoxysilane), with the aim to modify the mesoporous silica surface with amino group so urea not only intercalated on mesoporous silica's pore but also in amine functional group by hydrogen bond between nitrogen and hydrogen. The presence of amine functional group would increase the intercalation between adsorbent and adsorbate, so urea's adsorption increased [36]. FTIR spectrum of mesoporous silica and mesoporous silica-APTMS as seen in Figure 2, revealed characteristic absorption bands of ordered silica. The FTIR characterization results obtained spectra which shows the appearance of certain peaks at wavenumber with a certain absorbance, then identified the appearance of those peaks indicates the presence of certain functional groups. Based on the FTIR characterization analysis it can determine that there are differences in mesoporous silica without APTMS modification and after modification. There are several peaks that each of it has identical to one functional group, from FTIR result we can referred that there are some functional group on it. The higher absorbance of one specific functional group implied that it has high intensity of it, in Figure 2 there are several new peak arise indicate that amine functional group successfully modified mesoporous silicas's surface. But there are increased absorbance in several original peak indicated that the intensity is higher because of modification.

Peak at around $3500-3000 \mathrm{~cm}^{-1}$ is a stretching vibration of amine, couldn't be distinguish because an extensive broad extended to $\mathrm{OH}$ stretch of water intake physically at $3700-2700 \mathrm{~cm}^{-1}$. NH vibration covered by a wide band of adsorbed water $\mathrm{O}-\mathrm{H}$ prolonged band of the outside of silanol gatherings and the remaining adsorbed water atoms, because its overlapping each other. Axial deformation of the practical amine additionally covered of the extending vibration groups of Si-OH [27],[37],[38]. The peak appearing at $2930 \mathrm{~cm}^{-1}$ 
was ascribed to $\mathrm{CH}_{2}$ and $\mathrm{CH}_{3}$ stretching modes, elongation bands of $-\mathrm{CH}_{3}$ and $-\mathrm{CH}_{2}$ containing in amino silanes, $\mathrm{CH}$ stretching in $\mathrm{CH}_{2} \mathrm{CH}_{2} \mathrm{CH}_{2} \mathrm{NH}_{2}$, vibration of $\mathrm{CH}_{2}$ groups of the propyl chain of the silylating agent [27],[37]. The $1100 \mathrm{~cm}^{-1}$ broad absorption bands were ascribed to stretching vibrations of SiOSi while the $1630 \mathrm{~cm}^{-1}, 790 \mathrm{~cm}^{-1}$ and $450 \mathrm{~cm}^{-1}$ were attribute to $\mathrm{SiO}-\mathrm{H}$ bending, $\mathrm{SiO}-\mathrm{H}$ symmetrical stretching and $\mathrm{Si}-\mathrm{O}$ bending vibrations, respectively. Vibrational modes

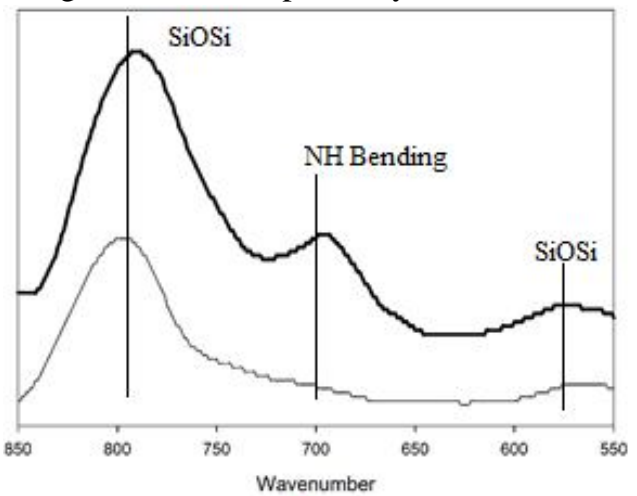

(a)

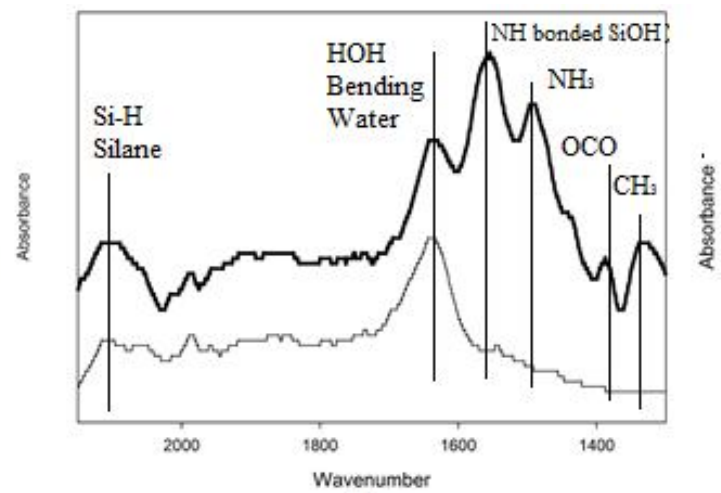

(b)

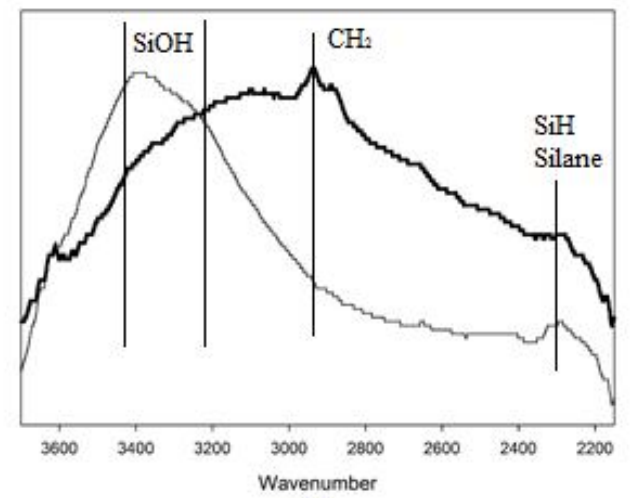

at $155 \mathrm{~cm}^{-1}$ represent $\mathrm{NH}_{2}$ scissoring, $\mathrm{NH}_{2}$ symmetric bending vibration, $\mathrm{NH}_{2}$ scissoring vibration, bending $\mathrm{NH}$, amine bonding of $\mathrm{NH}_{2} \mathrm{H}$-bonded $\mathrm{SiOH}$ group [39].

Further reading can improve integration and application in different field such as [40], [41] and [42].

(c)

Figure 2: FTIR for Mesoporous Silica and Mesoporous Silica-APTMS (a)3700-2150 $\mathrm{cm}^{-1}$ (b)2150-1300 $\mathrm{cm}^{-1}(\mathrm{c}) 850-550 \mathrm{~cm}^{-1}$

\section{CONCLUSION}

Mesoporous silica obtained using cetyltrimethylammonium bromide (CTAB) as surfactant and sodium silicate as a precursor. Sodium silicate obtained by adding silica with $\mathrm{NaOH}$. The effects of sodium silicate also have different effects on the pore produced.. The BET analysis ensured the characterization of the silica product in pore radius, pore-volume, surface area and adsorption-desorption curves. Mesoporous silica synthesis with 0.03 mol of CTAB revealed the diameter are 15,310 $\AA$ and 19,025 $\AA$ at adsorption and desorption, respectively. The pore diameters were in the range of $2 \mathrm{~nm}-50 \mathrm{~nm}$, indicate that mesoporous particle was produced. Also, having the adsorption-desorption curve type of IV which classified as the mesoporous particle. Modification done by adding APTMS (3Aminopropyltrimethoxysilane), the modified mesoporous silica characterized by using FTIR. Several functional groups indicate ammonia from APTMS have been modified the mesoporous silica, such as $2930 \mathrm{~cm}^{-1}$ corresponding to $\mathrm{CH}_{2}$ groups Stretching modes and Vibrational modes at $155 \mathrm{~cm}^{-1}$ represent $\mathrm{NH}_{2}$.

\section{ACKNOWLEDGEMENT}

The authors would like to express their sincere gratitude's to the Ministry of Research and Higher Education of Indonesia, Indonesia for the financial support received under the research project of Program Thesis Magister (PTM) with contract number : 258-19/UN7.P4.3/PP/2019. Also appreciation goes to the Advanced Materials Laboratory (AMaL) and colleagues who have provided support throughout the course of this study.

\section{REFERENCES}

1. S. K. De Datta. Advances in soil fertility research and nitrogen fertilizer management for lowland rice, Efficiency of nitrogen fertilizers for rice, pp. 27-41, 1987. 
2. R. Hidayat, G. Fadillah, U. Chasanah, S. Wahyuningsih, and A. H. Ramelan. Effectiveness of urea nanofertilizer based aminopropyltrimethoxysilane (APTMS)-zeolite as slow release fertilizer system, African Journal of Agricultural Research, vol. 10, no. 14, pp. 1785-1788, 2015.

3. A. Bernhard. Nitrogen is one of the primary nutrients critical for the survival of all living organisms. Although nitrogen is very abundant in the atmosphere, it is largely inaccessible in this form to most organisms. This article explores how nitrogen becomes avai, Nature Education Knowledge, vol. 2, no. 2, pp. 1-8, 2010.

4. G. D. Nainggolan, Suwardi, and Darmawan. Pattern of Nitrogen Release from Slow Release of Natural Urea-Zeolite Fertilizer (Pola Pelepasan Nitrogen dari Slow Release Fertilizer Urea-Zeolit Alam), Jurnal Zeolit Indonesia, vol. 8, no. 2, pp. 89-96, 1997.

5. P. Erkekoglu, H. Sipahi, and T. Baydar. Evaluation of nitrite in ready-made soups, Food Analytical Methods, vol. 2, no. 1, pp. 61-65, 2009.

6. B. Azeem, K. Kushaari, Z. B. Man, A. Basit, and T. H. Thanh. Review on materials \& methods to produce controlled release coated urea fertilizer, Journal of Controlled Release, vol. 181, no. 1, pp. 11-21, 2014.

7. R. Prasad, S. Singh, V. S. Saxena, and C. Devkumar. Coating of prilled urea with neem (azadirachta indica juss) oil for efficient nitrogen use in rice. Naturwissenschaften, vol. 86, no. 11, pp. 538-539, 1999.

8. Z. Zhu, and R. Zhuo. Slow release behavior of starch-g-poly(vinyl alcohol) matrix for 2,4,5-trichlorophenoxyacetic acid herbicide. European Polymer Journal, vol. 37, no. 9, pp. 1913-1919, 2001.

9. L. Chen, X. Qiu, M. Deng, Z. Hong, R. Luo, X. Chen, and $X$. Jing. The starch grafted poly(l-lactide) and the physical properties of its blending composites, Polymer, vol 46, no. 15, pp. 5723-5729, 2005.

10. L. Chen, Z. Xie, X. Zhuang, X. Chen, and X. Jing. Controlled release of urea encapsulated by starch-g-poly(l-lactide), Carbohydrate Polymers, vol. 72, no. 2, pp. 342-348, 2008.

11. S. Jin, Y. Wang, J. He, Y. Yang, X. Yu, and G. Yue. Preparation and properties of a degradable interpenetrating polymer networks based on starch with water retention, amelioration of soil, and slow release of nitrogen and phosphorus fertilizer. Journal of Applied Polymer Science, vol. 128, no. 1, pp. 407-415, 2013.

12. K. Saleh, D. Steinmetz, and M. Hemati. Experimental study and modeling of fluidized bed coating and agglomeration Powder Technology, vol. 130, no. 1-3, pp. 116-123, 2003.

13. J. R. Martínez, S. Palomares-Sánchez, G. Ortega-Zarzosa, F. Ruiz, and Y. Chumakov. Rietveld refinement of amorphous $\mathrm{SiO} 2$ prepared via sol-gel method, Materials Letters, vol. 60, no. 29-30, pp. 3526-3529, 2006.

14. S. Silviana, and W. J Bayu. Silicon Conversion from Bamboo Leaf Silica by Magnesiothermic Reduction for Development of Li-ion Baterry Anode, MATEC Web of Conferences, vol. 156, pp. 0-3, 2018.

15. S. Affandi, H. Setyawan, S. Winardi, A. Purwanto, and R. Balgis. A facile method for production of high-purity silica xerogels from bagasse ash, Advanced Powder Technology, vol. 20, no. 5, pp. 468-472, 2009.

16. A. Purnomo, F. Dalanta, A. D. Oktaviani, and S. Silviana. Superhydrophobic coatings and self-cleaning through the use of geothermal scaling silica in improvement of material resistance, In $A I P$ Conference Proceedings, vol. 2026, no. 1, p. 020077 , 2018, AIP Publishing LLC.

17. E. Tri, S. Agustinus, H. Sembiring. Engineering Technology For Increasing Amorf Silica Added Value (Sio2) Dieng Heating Field As Geomaterial (Teknologi Rekayasa Untuk Peningkatan Nilai Tambah Silika Amorf (Sio2 ) Lapangan Panasbumi Dieng Sebagai Geomaterial), pp. 379-388, 2014.

18. M. Mohseni, K. Gilani, and S. A. Mortazavi. Preparation and characterization of rifampin loaded mesoporous silica nanoparticles as a potential system for pulmonary drug delivery, Iranian Journal of Pharmaceutical Research, vol. 14, no. 1, pp. 27-34, 2015.

19. J. Kärger, and R. Valiullin. Mass transfer in mesoporous materials: The benefit of microscopic diffusion measurement, Chemical Society Reviews, vol. 42, no. 9, pp. 4172-4197, 2013.

20. J. Knipping, H. Wiggers, B. Rellinghaus, P. Roth, D. Konjhodzic, and C. Meier. Synthesis of high purity silicon nanoparticles in a low pressure microwave reactor, Journal of Nanoscience and Nanotechnology, vol. 4, no. 8, pp. 1039-1044, 2004.

21. Y. Fang, and H. Hu. Mesoporous TS-1: Nanocasting synthesis with CMK-3 as template and its performance in catalytic oxidation of aromatic thiophene, Catalysis Communications, vol. 8, no. 5, pp. 817-820, 2007. https://doi.org/10.1016/j.catcom.2006.09.018

22. M. A. Tony, Y. Q. Zhao, P. J. Purcell, and M. F. El-Sherbiny. Evaluating the photo-catalytic application of Fenton's reagent augmented with $\mathrm{TiO} 2$ and $\mathrm{ZnO}$ for the mineralization of an oil-water emulsion, Journal of Environmental Science and Health Part A Toxic/Hazardous Substances and Environmental Engineering, vol. 44, no. 5, pp. 488-493, 2009.

23. H. Wanyika, E. Gatebe, P. Kioni, Z. Tang, and Y. Gao. Mesoporous silica nanoparticles carrier for urea: Potential applications in agrochemical delivery systems, Journal of Nanoscience and Nanotechnology, vol. 12, no. 3, pp. 2221-2228, 2012. 
24. N. I. Vazquez, Z. Gonzalez, B. Ferrari, and Y. Castro. Synthesis of mesoporous silica nanoparticles by sol-gel as nanocontainer for future drug delivery applications, Boletin de La Sociedad Espanola de Ceramica y Vidrio, vol. 56, no. 3, pp. 139-145, 2017.

25. A. Popat, S. B. Hartono, F. Stahr, J. Liu, S. Z. Qiao, and G. Q. Lu. Mesoporous silica nanoparticles for bioadsorption, enzyme immobilisation, and delivery carriers, Nanoscale, vol. 3, no. 7, pp. 2801-2818, 2011.

26. H. Rahmat, F. Ganjar, C. Uswatul, W. Sayekti, and H. R. Ari. Effectiveness of urea nanofertilizer based aminopropyltrimethoxysilane (APTMS)-zeolite as slow release fertilizer system, African Journal of Agricultural Research, vol. 10, no. 14, pp. 1785-1788, 2015.

27. B. Boukoussa, A. Hakiki, N. Bouazizi, A. P. Beltrao-Nunes, F. Launay, A. Pailleret, A. Azzouz. Mesoporous silica supported amine and amine-copper complex for $\mathrm{CO} 2$ adsorption: Detailed reaction mechanism of hydrophilic character and CO2 retention, Journal of Molecular Structure, vol. 1191, pp. 175-182, 2019.

28. L. Trivana, S. Sugiarti, and E. Rohaeti. Syhthesis and Characterized Sodium Silicate (Na2SiO3) from Rice Husk (Sintesis Dan Karakterisasi Natrium Silikat (Na2Sio3) Dari Sekam Padi), Jurnal Sains \&Teknologi Lingkungan, vol. 7, no. 2, pp. 66-75, 2015.

29. M. Jaishankar, T. Tseten, N. Anbalagan, B. B. Mathew, and K. N. Beeregowda. Toxicity, mechanism and health effects of some heavy metals, Interdisciplinary Toxicology, vol. 7, no. 2, pp. 60-72, 2014.

30. D. Fraenkel. Structure and ionization of sulfuric acid in water, New J. Chem., vol. 39, no. 7, pp. 5124-5136, 2015.

31. E. P. Barrett, L. G. Joyner, and P. P. Halenda. The Determination of Pore Volume and Area Distributions in Porous Substances. I. Computations from Nitrogen Isotherms, Journal of the American Chemical Society, vol. 73, no. 1, pp. 373-380, 1951.

32. D. Do Duong. Adsorption Analysis: Equilibria And Kinetics (With CD Containing Computer Matlab Programs), World Scientific, vol 2, 1998.
33. S. Zhang, G. L. Li, H. L. Cong, B. Yu, and X. Y. Gai. Size control of monodisperse silica particles by modified Stöber method, Integrated Ferroelectrics, vol. 178, no. 1, pp. 52-57, 2017.

34. W. Li, J. Liu, and D. Zhao. Mesoporous materials for energy conversion and storage devices, Nature Reviews Materials, vol. 1, no. 6, p. 16023, 2016.

35. Z. A. Alothman. A review: Fundamental aspects of silicate mesoporous materials, Materials, vol. 5, no. 12, pp. 2874-2902, 2012.

36. W. K. Cheah, Y. L. Sim, and F. Y. Yeoh. Amine-functionalized mesoporous silica for urea adsorption, Materials Chemistry and Physics, vol. 175, pp. 151-157, 2016.

37. M. Barczak. Amine-modified mesoporous silicas: Morphology-controlled synthesis toward efficient removal of pharmaceuticals, Microporous and Mesoporous Materials, vol. 278, pp. 354-365, 2019.

38. R. C. Puerari, E. Ferrari, M. G. de Cezar, R. A. Gonçalves, C. Simioni, L. C. Ouriques, W. G. Matias. Investigation of toxicological effects of amorphous silica nanostructures with amine-functionalized surfaces on Vero cells, Chemosphere, vol. 214, pp. 679-687, 2019.

39. L. D. White, and C. P. Tripp. Reaction of (3-aminopropyl)dimethylethoxysilane with amine catalysts on silica surfaces, Journal of Colloid and Interface Science, vol. 232, no. 2, pp. 400-407, 2000.

40. Ivanov, V.A. Reconditioning of worn process equipment using composite materials, International Journal of Emerging Trends in Engineering Research 8(6),68, pp. 2635-2642, 2020. https://doi.org/10.30534/ijeter/2020/68862020

41. Ivanov, V.A. Wear resistance of repair composite materials with ceramic fillers, International Journal of Emerging Trends in Engineering Research 8(4),39, pp. 1192-1195, 2020. https://doi.org/10.30534/ijeter/2020/39842020

42. Siswanto, W.A., Anggono, A.D., Omar, B., Jusoff, K. An alternate method to springback compensation for sheet metal forming, Scientific World Journal, 2014,301271, 2014. 